\title{
Fine-scale three-dimensional spatial use by diving, lactating female Weddell seals Leptonychotes weddellii
}

\author{
Mark A. Hindell ${ }^{1, *}$, Robert Harcourt ${ }^{2}$, Joseph R. Waas ${ }^{3}$, David Thompson ${ }^{4}$ \\ ${ }^{1}$ Antarctic Wildlife Research Unit, School of Zoology, University of Tasmania, PO Box 252-05, Hobart, Tasmania 7001, Australia \\ ${ }^{2}$ Marine Mammal Research Group, Graduate School of the Environment, Macquarie University, Sydney, New South Wales 2109, \\ Australia \\ ${ }^{3}$ Department of Biological Sciences, University of Waikato, Private Bag 3105, Hamilton, New Zealand \\ ${ }^{4}$ Sea Mammal Research Unit, Gatty Marine Laboratory, University of St Andrews, St Andrews, Fife, KY16 8LB, United Kingdom
}

\begin{abstract}
Despite the importance of fine-scale spatial use in understanding an animal's foraging ecology, these data cannot readily be collected for free-ranging marine mammals. We used an acoustic positioning system to quantify, for the first time, the fine-scale 3-dimensional (3D) spatial use of free-ranging Weddell seals swimming under ice. Unlike many other phocid species, lactating Weddell seals spent up to $25 \%$ of their time diving. Given the limited foraging range imposed on the seals by the fast ice upon which they breed, this could lead to prey depletion and even inter-specific competition. The seals focused their underwater activity on a relatively small region associated with a steep bottom contour, using the entire water column, with very little time spent at the bottom. This behaviour is consistent with feeding on bentho-pelagic prey such as Pleurogramma antarcticum. The 3D profile of individual dives consisted of the seals making simple, directed dives which gradually converged with the ocean floor. There was some variation from this pattern, usually associated with increased searching time. Such focused foraging activity may result in local prey depletion and intraspecific competition.
\end{abstract}

KEY WORDS: Three-dimensional tracking · Acoustic tracking · Habitat use - Intra-specific competition · Weddell seals

\section{INTRODUCTION}

Fine-scale habitat use is fundamental to understanding many key aspects of an animal's ecology. Even animals with large home ranges often concentrate their activities on small patches where they locate food, mates and shelter. When large numbers of animals overlap in range, these patches are likely to be subject to high levels of use, and therefore potential sites of competition. Obtaining quantitative measures of finescale habitat use is therefore the first step to evaluating the extent of intra-specific resource competition.

For marine mammals, quantifying fine-scale habitat use has proven extremely difficult, for 2 reasons.

*E-mail: mark.hindell@utas.edu.au
First, many species live most of their lives submerged in open water, where they are effectively invisible to observers. As a result, movements are generally recorded remotely using some form of instrumentation. Of the methods currently used to locate free-ranging animals, satellite telemetry is the preferred method (e.g. Hull et al. 1997). Satellite telemetry has a resolution of 1000s of metres, which precludes habitat analysis at all but mesoscale and above (McConnell et al. 1992a, 1999, Sjoberg $\&$ Ball 2000). Finer-scale studies of habitat use by marine mammals are currently limited to Harbour seals Phoca vitulina, where researchers have used VHF telemetry (Stewart et al. 1989, Thompson et al. 1991, Tollit et al. 1998), which has higher resolution than satellite telemetry, but these studies must assume that the surface location of the seal corresponds to the habitat it exploits. 
This leads to a second problem: whereas for most terrestrial mammals, quantification of fine-scale habitat use requires information from only 2 dimensions, marine mammals live in 3-dimensional (3D) habitats (Davis et al. 1999, Harcourt et al. 2000, Simpkins et al. 2001a,b). Zamon et al. (1996) have shown that biologically important features of prey patchiness cannot be addressed within the limitations of a 2-dimensional analysis. They reported that associations of penguins to krill abundance were significant only for 30 to $40 \mathrm{~m}$ depth aggregations and were masked when density over the whole column was integrated. As some marine mammal species, such as elephant seals Mirounga spp. (Hindell et al. 1992) and northern bottlenose whales Hyperoodon ampullatus (Hooker \& Baird 1999), reach depths in excess of $1000 \mathrm{~m}$ and stay submerged for over $1 \mathrm{~h}$, surface location may give little information on the use of the water column or the benthic region.

Recently a small number of studies have successfully quantified true 3D diving behaviour of seals, focusing on the form and function of individual dives, rather than on details of overall spatial use (Wartzok et al. 1992a, Davis et al. 1999, 2001, Harcourt et al. 2000, Simpkins et al. 2001a,b). True 3D data are those where the 2 horizontal and the vertical coordinates are collected simultaneously while the animal is swimming. While they constitute a major advance in studies of marine mammal diving, these studies generated new analytical problems, such as increased number of variables and visual representation of data.

For lactating Weddell seals Leptonychotes weddellii, fine-scale habitat use is of particular importance. During the breeding season female Weddell seals haul out in groups of 10 to 100 individuals on fast ice often many kilometers from the nearest open water (Bartsh et al. 1992). The females face considerable energetic demands from their pups, which increase in mass from $30 \mathrm{~kg}$ at birth to over $150 \mathrm{~kg}$ at weaning in the space of 50 to 55 d (Tedman \& Bryden 1981, Tedman \& Green 1987). A common lactation strategy by phocid seals is for females to fast during lactation, and to wean pups quickly, usually in 2 to $3 \mathrm{wk}$ (Costa 1991). As female Weddell seals have an extended period of lactation and high absolute energy transfer requirements, it is generally believed that they break this pattern and forage during lactation in order to meet their energy requirements (Costa 1991).

In some situations, seals breeding on fast ice may only have access to the water through a single tide crack. Foraging will therefore be restricted to the immediate vicinity of the colony, within a radius that is determined by how far the animals can travel on a single breath hold dive before they return to their point of origin (or near to it) (Davis et al. 1999). This is likely to be in the order of 1 to $2 \mathrm{~km}$, based on aerobic capacity and swimming speed of seals of this size (Kooyman et al. 1980, Ponganis et al. 1993, Burns \& Castellini 1996). Up to one hundred, 300 to $500 \mathrm{~kg}$ lactating animals feeding within such a small region over several weeks may cause prey depletion and may therefore generate intra-specific competition between individuals.

The first step in understanding these issues is to investigate in detail how the seals are utilising the limited space available. This study therefore had 2 specific aims. The first was to quantify the 3D fine-scale habitat use of free-ranging, lactating Weddell seals. For the purposes of this study we regard 'fine-scale' as less than $100 \mathrm{~m}$. The second aim was to describe individual dive trajectories in $3 \mathrm{D}$.

\section{MATERIALS AND METHODS}

Study site and bathymetry. The study was conducted at Turtle Rock, McMurdo Sound $\left(77.727^{\circ} \mathrm{S}, 166.85^{\circ} \mathrm{E}\right)$, which supported a Weddell seal colony of approximately 25 males and 45 females (Harcourt et al. 2000). The seals gained access to the water through a tide crack that ran in an approximately north-south direction just to the west of the rock, and the colony extended over an area of 300 to $400 \mathrm{~m}$.

The bathymetry of the surrounding area was measured using a LORAN JFC-20 echo sounderwith $0.5 \mathrm{~m}$ resolution. All measurements were made through $80 \mathrm{~mm}$ diameter holes drilled through the ice. The seaice thickness averaged $2 \mathrm{~m}$ throughout most of the study site. For the area immediately around the colony, depths were measured on a $50 \mathrm{~m} \times 50 \mathrm{~m}$ grid extending for $450 \mathrm{~m}$ along a northerly axis and $250 \mathrm{~m}$ on a westerly axis. Depth was recorded up to $850 \mathrm{~m}$ to the south and east of Turtle Rock, but these determinations were less systematic and up to $200 \mathrm{~m}$ apart. Full bathymetric coverage of the area was generated using a linear interpolation routine in SAS (SAS 1988).

Study animals. A total of 5 lactating Weddell seals were immobilized by an intra-muscular injection of Ketamine/Diazepam at a dose rate of approximately $2.0 \mathrm{mg}(100 \mathrm{~kg})^{-1}$ Ketamine: $0.4 \mathrm{mg}(100 \mathrm{~kg})^{-1}$ Diazepam; 3 seals were captured during the 1998 breeding season, and 2 during the 1999 breeding season. We glued a cylindrical depth-modulated acoustic transmitter (Vemco V16P, individual frequencies from 60 to $76.8 \mathrm{kHz}, 16 \times 115 \mathrm{~mm}$, mass $33 \mathrm{~g}$ ), and a VHF radio transmitter (Sirtrack $28 \times 15 \times 60 \mathrm{~mm}$, antenna $240 \mathrm{~mm}$, mass $28 \mathrm{~g}$ ) to the dorsal surface of each seal using quick-dry Epoxy (Araldite no. 2017).

Three-dimensional locations. Movements under the ice were monitored using a Cabled Acoustic Positioning System manufactured by Vemco Limited, de- 
scribed in detail in Harcourt et al. (2000), similar to the system used by Wartzok et al. (1992a,b). A triangular array of 3 omni-directional hydrophones (Vemco VH65, 50-80 kHz), each connected to an Ultrasonic Acoustic Receiver (Vemco VR20), was placed around the colony on the southern side of Turtle Rock. The distance between receivers in 1998 was A-C: $461 \mathrm{~m}, \mathrm{C}-\mathrm{B}$ : $508 \mathrm{~m}$ and B-A: $478 \mathrm{~m}$ and in 1999 was A-C: $435 \mathrm{~m}$, C-B: $469 \mathrm{~m}$ and B-A: $476 \mathrm{~m}$. Each receiver was connected via communication cables (length $308 \mathrm{~m}$ ) to a central base station. Hydrophones were placed through the sea-ice (thickness 1.4 to $2.2 \mathrm{~m}$ ) via $80 \mathrm{~mm}$ diameter holes and suspended in $3 \mathrm{~m}$ long doublewalled PVC pipes. Each hydrophone was held securely at a depth of $3 \mathrm{~m}$ below sea level or between 0.8 and $1.6 \mathrm{~m}$ below the undersurface of the ice. Locations of each animal under the ice were measured using the software POSITION V3.07 $\left(\mathrm{Vemco}^{\circ}\right)$ that calculated the $x, y$ coordinates of each transmitter based on differences in the arrival time of pulses at each of the hydrophones, and determined depth $( \pm 1 \mathrm{~m})$ from modulating changes in pulse interval with depth. Each transmitter had been calibrated previously by Vemco and had a depth range of 0 to $680 \mathrm{~m}$.

Overall spatial use of the area. As the equipment recorded no locations while the seals were out of the water, the seals' time budget during the study could be divided into time spent hauled out, and time spent in the water on the basis of the acoustic location data. The raw 3D locations in the water were filtered to remove aberrant locations due to echoes when the seals were in shallow water or close to sub-surface ice ridges. This was done by calculating the speed required for the seal to move between subsequent locations, and removing any locations where this speed was greater than $4.5 \mathrm{~m}$ $\mathrm{s}^{-1}$ (Harcourt et al. 2000).

The times that the seals spent in each $50 \times 50 \times 50 \mathrm{~m}$ cube of space within the study area were then calculated. This was done by interpolating $x, y$ and $z$ positions at $5 \mathrm{~s}$ intervals between all consecutive locations made on each at-sea period. The number of these interpolated locations (each $5 \mathrm{~s}$ apart) was then calculated for each $50 \times 50 \times 50 \mathrm{~m}$ cube in the study area. The total spent (to the nearest second) in each grid was derived by multiplying this value by 5 .

Individual dive profiles. The complete 3D tracks were determined for 58 dives with a minimum of 10 fixes. They cannot be regarded as a truly random selection, and so we have made no attempt to use these data to examine the relative frequencies of different dive behaviours, but rather used them to indicate the range of behaviours the seals were exhibiting. Once suitable dives were identified, 19 variables were measured for each dive (Table 1). The variables were chosen to discriminate between directional (as opposed to 'looping') dives, benthic and mid-water dives, sit-and-wait and continuous search dives and dives with many changes in direction (Simpkins et al. 2001). These variables were then analysed using Multi-Dimensional Scaling (MDS) to identify similarities between the dives. The MDS was based on a Bray-Curtis similarity matrix, and ran on 99 random starts (PRIMER). The variables that were the most significant contributors to the observed pattern were determined by correlation of the MDS scores with the original values for each variable (Belbin 1993).

\section{RESULTS}

\section{Overall spatial use of the area}

The seals spent most their time hauled out in the company of their pups $(55.1 \pm 8.1 \%$, Table 2$)$. Despite

Table 1. Leptonychotes weddellii. Variables used to characterize the 3D shape of individual dives

\begin{tabular}{|c|c|c|}
\hline Variable & Mean $\pm \mathrm{SD}$ & Maximum \\
\hline Maximum depth (m) & $261.8 \pm 68.4$ & 386.0 \\
\hline Duration (min) & $26.14 \pm 10.92$ & 62.4 \\
\hline $\begin{array}{l}\text { Distance from start to } \\
\text { end point }(\mathrm{m})\end{array}$ & $72.7 \pm 74.4$ & 326.2 \\
\hline $\begin{array}{l}\text { Maximum distance from } \\
\text { start point in the } \\
\text { horizontal plane (m) }\end{array}$ & $564.5 \pm 217.9$ & 1219.5 \\
\hline $\begin{array}{l}\text { Maximum overall distance } \\
\text { (MOD) from start point (m) }\end{array}$ & $616.6 \pm 222.2$ & 1273.6 \\
\hline $\begin{array}{l}\text { Total distance (TD) covered } \\
\text { during the dive }(\mathrm{m})\end{array}$ & $1507.3 \pm 554.3$ & 3098.2 \\
\hline $\begin{array}{l}\text { Linearity index } 1 \\
\text { (TD/MOD) }(\mathrm{m})\end{array}$ & $2.47 \pm 0.43$ & 3.70 \\
\hline $\begin{array}{l}\text { Linearity index } 2 \\
\quad(\mathrm{TD} /[\mathrm{TD}-\mathrm{MOD} \times 2])(\mathrm{m})\end{array}$ & $83.27 \pm 13.01$ & 4.50 \\
\hline $\begin{array}{l}\text { Minimum distance to the ocean } \\
\text { floor during the dive }(\mathrm{m})\end{array}$ & $54.7 \pm 35.4$ & 131.3 \\
\hline $\begin{array}{l}\text { Percentage of fixes within } \\
20 \mathrm{~m} \text { of the ocean floor }\end{array}$ & $2.1 \pm 0.4$ & 23.1 \\
\hline Mean speed $\left(\mathrm{m} \mathrm{s}^{-1}\right)$ & $1.33 \pm 0.33$ & 2.1 \\
\hline Maximum speed $\left(\mathrm{m} \mathrm{s}^{-1}\right)$ & $2.67 \pm 1.03$ & 4.6 \\
\hline Minimum speed $\left(\mathrm{m} \mathrm{s}^{-1}\right)$ & $0.34 \pm 0.26$ & 1.4 \\
\hline $\begin{array}{l}\text { Minimum speed when within } \\
20 \mathrm{~m} \text { of ocean floor }\left(\mathrm{m} \mathrm{s}^{-1}\right)^{\mathrm{a}}\end{array}$ & $1.38 \pm 0.52$ & 4.5 \\
\hline Mean acceleration $\left(\mathrm{m} \mathrm{s}^{-2}\right)^{\mathrm{b}}$ & $0.35 \pm 0.33$ & 1.52 \\
\hline $\begin{array}{l}\text { Horizontal angular velocity } \\
\left(\text { deg s}^{-1}\right)^{\mathrm{b}}\end{array}$ & $1.90 \pm 1.42$ & 7.8 \\
\hline Horizontal directionality (deg) & $0.19 \pm 0.13$ & 0.60 \\
\hline $\begin{array}{l}\text { Vertical angular velocity } \\
\qquad\left(\text { deg s}^{-1}\right)^{\mathrm{b}}\end{array}$ & $2.19 \pm 1.73$ & 10.6 \\
\hline $3 \mathrm{D}$ angular velocity $\left(\mathrm{deg} \mathrm{s}^{-1}\right)^{\mathrm{b}}$ & $0.77 \pm 0.69$ & 4.4 \\
\hline Meander $\left.(\operatorname{deg~s})^{-1}\right)^{b}$ & $0.58 \pm 0.47$ & 2.8 \\
\hline
\end{tabular}



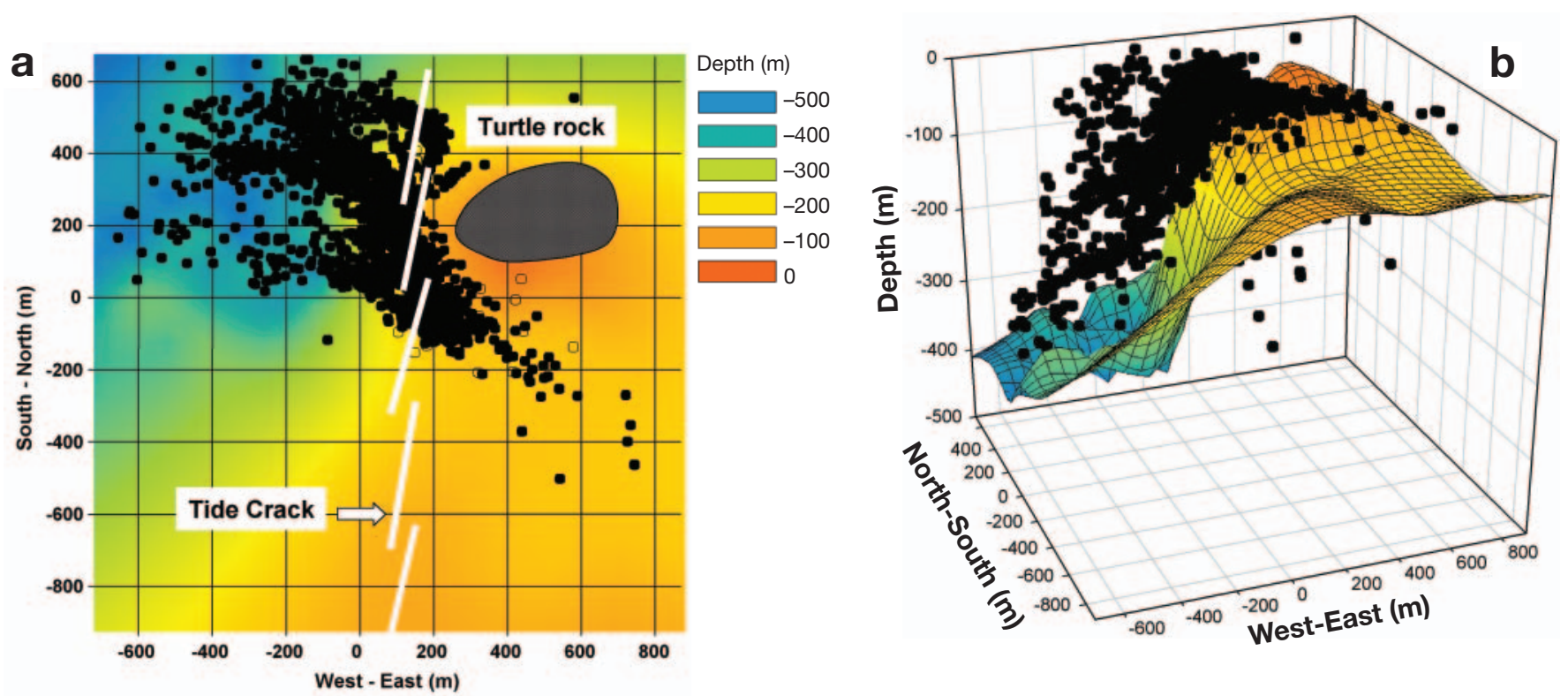

Fig. 1. Leptonychotes weddellii. (a) 2D and (b) 3D representation of all locations of female Weddell seals in relation to the bathymetry of the region; note that due to small errors in location estimates and interpolations in bathymetry, some of the locations appear to fall below the ocean floor

this, all 5 seals made numerous long dives away from the breeding colony. A total of 5618 3D locations were obtained (after filtering) while the seals were making these dives. The furthest location from the tide crack was $1.3 \mathrm{~km}$, which will have required the seal to make a minimum $2.6 \mathrm{~km}$ round trip on a single breath hold. Most locations were however within $700 \mathrm{~m}$ of the tide crack primarily to the northwest of the tide crack and to a lesser extent to the southeast (Fig. 1a). The NE quadrant of the region was occupied by Turtle Rock, and was unavailable to the seals, but the SW quadrant, which was freely accessible to the animals, was not used by our seals at all.

Table 2. Leptonychotes weddellii. Amounts of time spent underwater and in each $50 \mathrm{~m}$ depth stratum by 5 females

\begin{tabular}{|c|c|c|c|c|c|c|}
\hline Seal no. & F971 & O511 & Y1343 & Y1348 & Y14415 & \\
\hline Monitoring period (h) & 519.18 & 243.33 & 188.38 & 71.82 & 75.17 & \\
\hline Time hauled out (\%) & 43.8 & 53.5 & 52.8 & 65.1 & 60.5 & \\
\hline Total diving time (h) & 221.44 & 94.57 & 65.34 & 13.85 & 3.04 & \\
\hline Depth stratum (m) & \multicolumn{5}{|c|}{ Time in depth stratum (\%) } & Mean \pm SD \\
\hline $0-49$ & 57.09 & 37.19 & 17.54 & 75.89 & 58.06 & $49.15 \pm 22.36$ \\
\hline $50-99$ & 12.88 & 16.00 & 32.03 & 5.52 & 24.24 & $18.13 \pm 10.27$ \\
\hline $100-149$ & 8.44 & 11.30 & 16.96 & 10.34 & 12.61 & $11.93 \pm 3.20$ \\
\hline 150-199 & 7.37 & 9.37 & 28.28 & 7.75 & 4.99 & $11.55 \pm 9.48$ \\
\hline $200-249$ & 7.04 & 11.70 & 5.13 & 0.51 & 0.10 & $4.90 \pm 4.83$ \\
\hline $250-299$ & 4.86 & 10.90 & 0.05 & 0.00 & 0.00 & $3.16 \pm 4.81$ \\
\hline $300-349$ & 1.78 & 3.16 & 0.00 & 0.00 & 0.00 & $0.99 \pm 1.44$ \\
\hline $350-399$ & 0.14 & 0.34 & 0.00 & 0.00 & 0.00 & $0.10 \pm 0.15$ \\
\hline
\end{tabular}

\section{Spatial use with respect to depth}

The seals used the entire water column, spilling outwards and downwards over the bathymetric contour throughout the 3D space available to them (Fig. 1b). Nevertheless, the seals did not use the water column in a uniform manner (Table 2), as 4 of the 5 individuals spent most of their time (49.2 \pm $22.4 \%$ ) diving in the uppermost $50 \mathrm{~m}$ of the water column. Although one seal (Y1343) spent most of her time in the 50 to $99 \mathrm{~m}$ depth stratum, the general pattern was for the proportion of time spent in a stratum to decrease with increasing depth.

In order to quantify the relative use of the region in 3 dimensions, the proportion of the total amount of time spent diving was calculated for all $50 \times 50 \times 50 \mathrm{~m}$ cells in a region bounded by -1300 and $1300 \mathrm{~m}$ in the east-west dimension, -1300 and $1300 \mathrm{~m}$ in the north-south dimension and 0 to $400 \mathrm{~m}$ in depth. This was done for each of the 5 seals and then a mean value calculated for each cell, in order to produce an overall summary unbiased by different individual monitoring efforts. These data were then examined in successive $50 \mathrm{~m}$ depth strata (Fig. 2). 

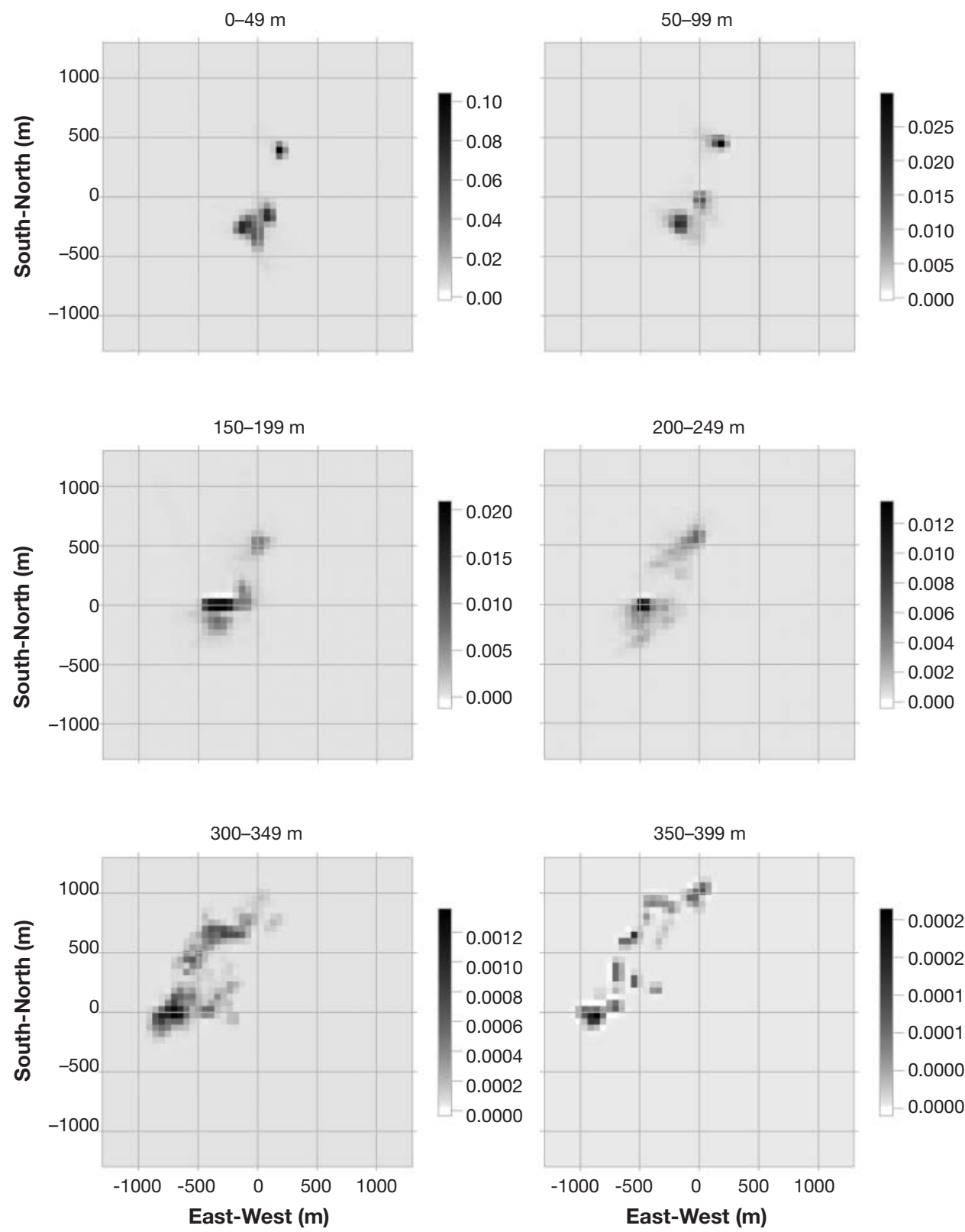

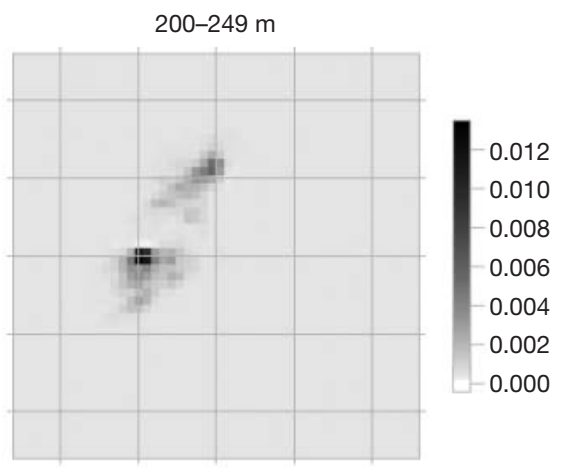

350-399 m

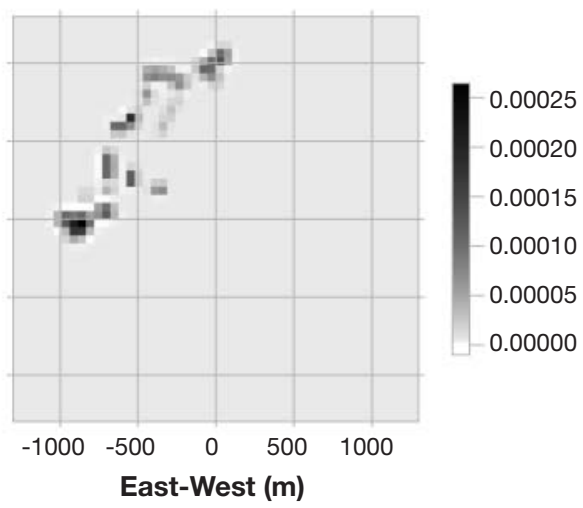

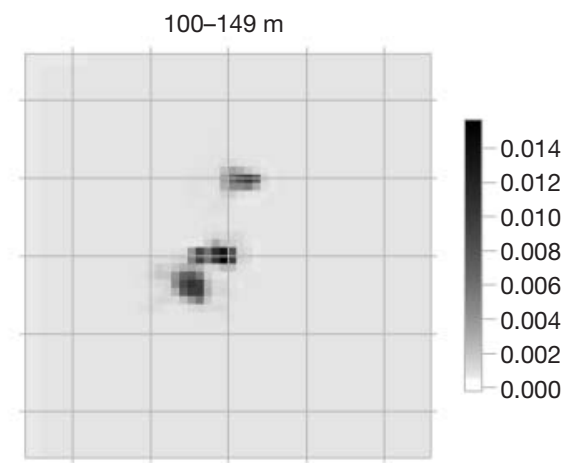

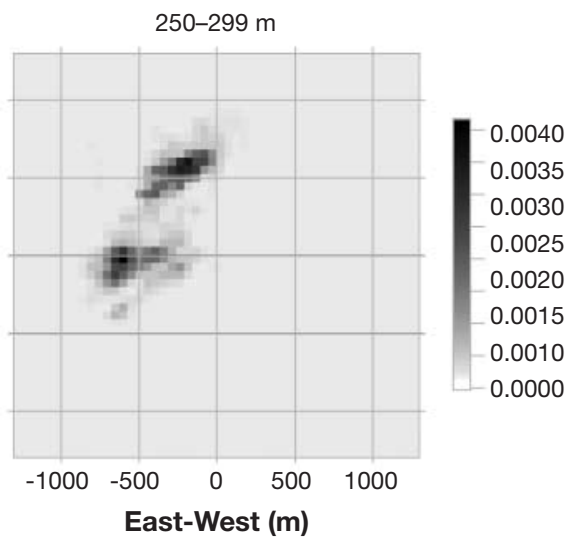

The seals spent most of their underwater time in the uppermost $50 \mathrm{~m}$ of the water column in the region immediately around the tide crack (Fig. 2) within 200 to $300 \mathrm{~m}$ of the the colony. They were never within $50 \mathrm{~m}$ of the surface when further away from the colony. In the 50 to $99 \mathrm{~m}$ layer of the water column, the seals were somewhat to the northwest of the colony. When in the 100 to $149 \mathrm{~m}$ strata they were even further from the tide crack, but still in a northwesterly direction. This pattern continued with increasing depth, until in the final 350 to 399 m layer there was a restricted arc of activity within a $1000 \mathrm{~m}$ radius of the tide crack.

\section{Spatial use with respect to the ocean floor}

The distance to the ocean floor was calculated for each location for each seal, and then these values were averaged for each $50 \times 50 \mathrm{~m}$ square in the horizontal dimension. An overall mean value for each square of each of the 5 seals was then calculated and examined as a contour plot (Fig. 3). The locations furthest from the ocean floor were those associated with the tide crack. The distance to the ocean floor decreased with increasing distance from the crack. At the extremities of the seal's distribution all locations were within $25 \mathrm{~m}$ of the bottom. This indicates that the seals were not 


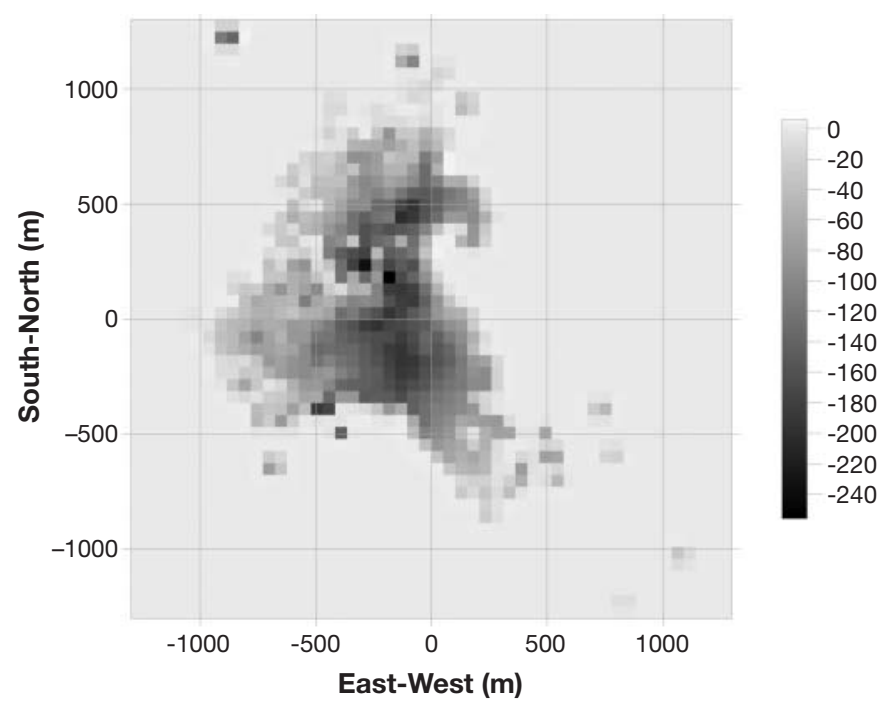

Fig. 3. Leptonychotes weddellii. Mean distance to the bottom for $3 \mathrm{D}$ locations grouped into $50 \times 50 \mathrm{~m}$ grid squares

immediately descending to the bottom, and then following it as they moved further from the colony. Rather, they converged on the bottom at a distance at approximately $700 \mathrm{~m}$ from the colony. However, the seals rarely went completely to the bottom, even in the relatively shallow water in the SE quadrant of the study area. Only 10 of the total 5618 locations were within $10 \mathrm{~m}$ of the bottom.

\section{Individual dive profiles}

The number of fixes used to quantify the 3D shape of individual dives ranged from 10 to $42($ mean $=16)$ at a rate of 0.19 to 2.19 fixes $\min ^{-1}$ (mean $=0.74$ fixes $\mathrm{min}^{-1}$ ). The general form of all 58 dives was similar, and consisted of the seals making long excursions from the tide crack and diving to between 100 and $400 \mathrm{~m}$. The seals covered on average a total distance of $1501 \mathrm{~m}$ on these dives, moving on average $529 \mathrm{~m}$ in a horizontal direction from the crack. They returned to within $10 \mathrm{~m}$ of their departure point on $15.5 \%$ of the dives. The mean dive duration was $26.1 \mathrm{~min}$ (overall maximum $62.0 \mathrm{~min}$ ), with a mean speed of $1.33 \mathrm{~m} \mathrm{~s}^{-1}$.

There were however, consistent differences between the dives. The MDS analysis obtained a stress level of 0.04 using only 2 dimensions indicating strong structure in the data. A plot of these 2 axes (Fig. 4) shows a continuum from dives with high meander, high 3D angular velocity, lower mean speed and a higher proportion of fixes within $20 \mathrm{~m}$ of the bottom, to dives with low meander, low 3D angular velocity, low mean speeds and low horizontal angular velocity. More simply, there were (1) highly directional dives in which the seal, upon reaching her maximum, depth returned immediately to the surface, retracing the outward path while maintaining a relatively high speed (e.g. Fig. 5b); (2) dives that tended to trace a loop where the outward and return legs followed different paths, with more frequent changes in direction in all planes and relatively low overall speed, where the seals approached the ocean floor (e.g. Fig. 5a); and (3) a range of dives between these 2 extremes.

On the majority of dives $(80 \%)$, the seals did not get to within $20 \mathrm{~m}$ of the ocean floor, and when they did, they only spent $2 \%$ of the time there. Further, the swimming speed of the animals during the time that they were at or close to the ocean floor was higher than the minimum speed recorded for that dive. Swim speed did not drop below $0.1 \mathrm{~m} \mathrm{~s}^{-1}$ at any time in the dives examined.

\section{DISCUSSION}

This study is the first quantitative description of the fine-scale 3D spatial use by a marine mammal. Earlier studies have described larger-scale spatial use patterns in 2 dimensions, e.g. in southern elephant seals (McConnell \& Fedak 1996), northern elephant seals (Le Boeuf et al. 2000), grey seals (McConnell et al. 1992b, 2002) and spotted dolphins (Davis et al. 1996), usually with spatial resolutions of $1 \mathrm{~km}$ or more. Other studies have quantified patterns of use in the vertical dimension, but most often these studies have dealt
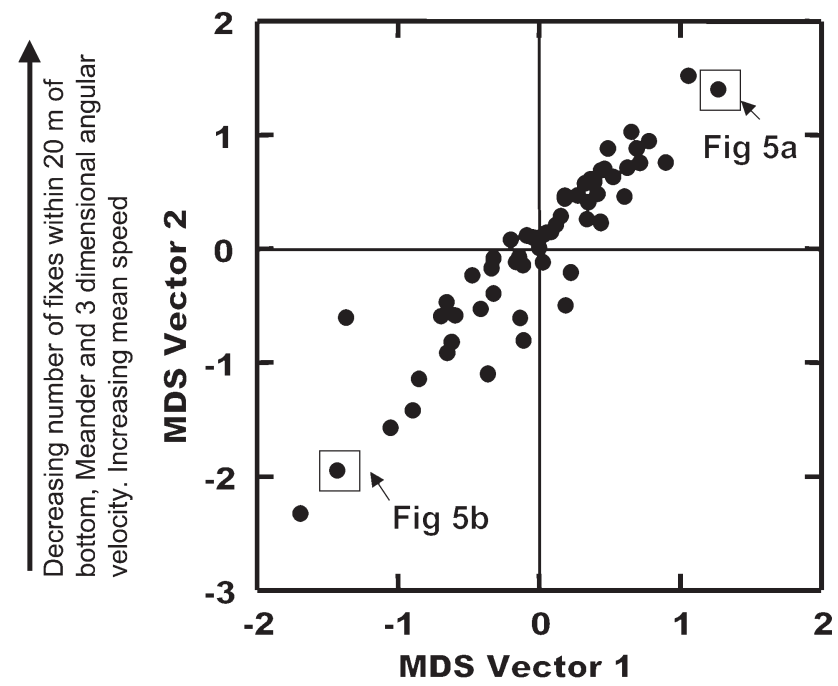

Decreasing number of fixes within $20 \mathrm{~m}$ of bottom, Meander and 3 dimensional angular velocity. Increasing mean speed

Fig. 4. Leptonychotes weddellii. Results of multi-dimensional scaling (MDS) analysis of 17 3D dive profile attributes 

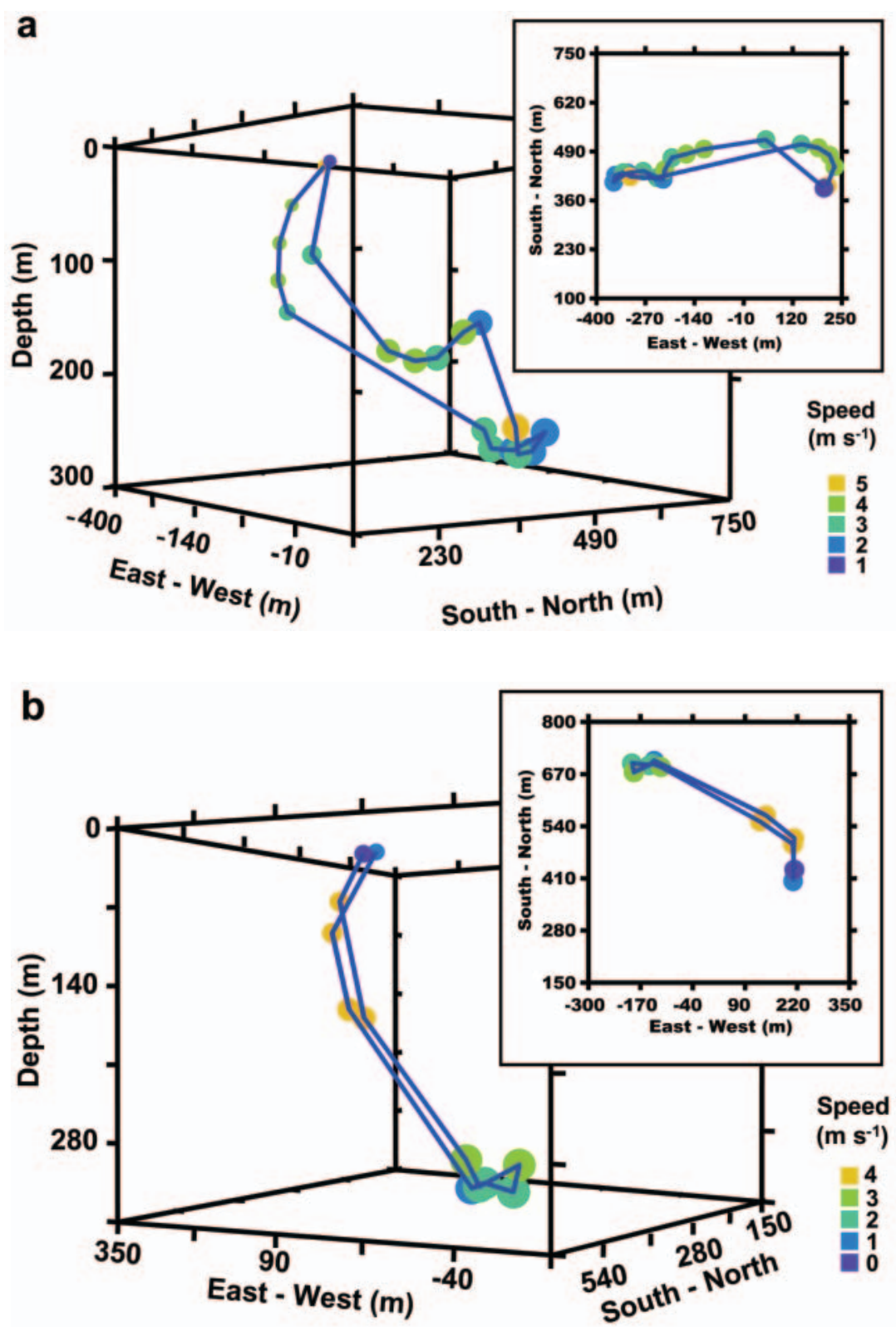

Fig. 5. Leptonychotes weddellii. Examples of individual 3D dive profiles. (a) Looping descent to the bottom of the dive; (b) directional dive with little meandering in the $x-y$ dimension. Top right insets show the horizontal tracks

have been unable to address questions relating to spatial use at the scale of $10 \mathrm{~s}$ to $100 \mathrm{~s}$ of meters. As this is the scale at which patches of marine prey tend to occur (e.g. Zamon et al. 1996), we lack a complete understanding of how marine mammals interact with and exploit their prey.

\section{Overall spatial use of the area}

The diving activity of lactating Weddell seals is unique among marine mammals. The extensive fast ice surrounding the breeding colonies means that access to open water, and therefore air at the end of a dive, is confined to the tide crack running through the colony (Fig. 1). Dives are therefore restricted to the distance that the seals can travel on a single breath. The furthest recorded distance from the colony in our study was $1.3 \mathrm{~km}$. This suggests that all of the diving and foraging activity of the 40 females in the colony was confined to an area of approximately $3.9 \mathrm{~km}^{2}$ (the area of a circle of $1.3 \mathrm{~km}$ radius less the area of Turtle Rock).

The 5 seals in this study exhibited both horizontal and vertical preferences. In the horizontal dimension, the seals concentrated their diving activity to an area to the northwest of the colony, towards the head of Erebus Bay. To a lesser extent, 1 seal (F971) also used the area to the southeast towards Hut Point Peninsula, but the area to the southwest, towards McMurdo Sound itself was never used. The absence of diving to the southwest may result from the small sample size or may indicate variations in food

with a single spatial dimension (e.g. Lydersen \& Hammill 1993, Harcourt et al. 1995, Bengtson \& Stewart 1997, Folkow \& Blix 1999, Hooker \& Baird 1999). Less frequently these 2 approaches have been coupled and vertical diving data were collected simultaneously with horizontal location data (Fedak et al. 1996, McConnell et al. 2002). This is achieved through the use of satellite-linked time depth recorders, or deployment of independent satellite transmitters and dive loggers (TDRs) on the same animal. These studies have revealed much about broad-scale habitat use, but they availability. The principle prey of Weddell seals in McMurdo Sound is the pelagic silverfish Pleurogramma antarcticum (Castellini et al. 1992, Burns et al. 1998), which makes up $90 \%$ of the fish biomass in the Sound; it has a patchy distribution and may be found anywhere in the water column (Knox 1994). The seals also take large Dissostichus mawsoni from deep in the water column (Davis et al. 1999). Elsewhere in Antarctica, Weddell seals feed on a range of prey including pelagic $P$. antarcticum, Trematomus spp., decapod crustaceans and cephalopods (Clarke \& MacLeod 
1982, Plotz 1986, Plotz et al. 1991, Green et al. 1995). The diet varies spatially and temporally (Green \& Burton 1987), suggesting that the seals are opportunistic feeders exploiting a large range of prey and habitats. Most of the prey species reported at other locations are also available to seals in McMurdo Sound (Knox 1994). Weddell seal pups from Hutton Cliffs, a colony less than $5 \mathrm{~km}$ from the Turtle Rock colony, feed primarily on young $P$. antarcticum (Burns et al. 1998). Yearlings also feed on $P$. antarcticum, but within this age group, larger individuals feed on bentho-pelagic prey, such as D. mawsoni and Trematomus spp. (Burns \& Testa 1997).

The seals used the water column (vertical dimension) in a non-uniform manner. Most of the time spent diving (as opposed to being in the water resting or interacting with their pups) was spent in the top $50 \mathrm{~m}$. However, almost all of the time spent in the top $50 \mathrm{~m}$ was also spent in the area immediately adjacent to the colony. The seals may be feeding in this region, perhaps on under-ice Pleurogramma antarcticum (Davis et al. 1999). This may also have been what the seals were doing during the small amount of time that they spent in the shallow water to the southeast. The seals also spend some of time in the shallow water near the tide crack when they start and finish their dives, but they must also have used this region for other, non-feeding activities close to the colony. For example, they may be with their pups, which are starting to swim (Burns \& Testa 1997), or they may be interacting with breeding males, which compete for access to the breathing holes associated with breeding colonies (Bartsh et al. 1992).

Our data suggest that the seals did not forage immediately under the ice at distances greater than $300 \mathrm{~m}$ from the colony. Indeed, the seals used a narrow depth range, which increased as a function of distance from the colony. This pattern is consistent with the seals traversing the same path, or set of paths, on all dives. Although relatively little time was spent in the 350 to $399 \mathrm{~m}$ depth class, the cells that were used at that depth displayed a pronounced arc around the colony. The points used when the seals were at their maximum depths were all approximately $1100 \mathrm{~m}$ from the colony. This would require a $2.3 \mathrm{~km}$ round trip (assuming there is no meandering and allowing for a maximum depth of $350 \mathrm{~m}$ ), and at the average swimming speed of seals in the study this would take the seals approximately $51 \mathrm{~min}$. It seems likely that this distance is the maximum attainable on a single breath-hold for actively swimming Weddell seals.

These end points were not on the ocean floor, but close to it, generally to within $50 \mathrm{~m}$. Even when foraging in relatively shallow waters to the southeast, the same pattern was apparent, with the most distant points occurring within $50 \mathrm{~m}$ of the bottom, but not actually on the bottom. This is consistent with the seals exploiting bentho-pelagic prey species, such as Dissostichus mawsoni, rather than epi-pelagic species, as has been reported for other pinniped species (DeLong \& Stewart 1991, Hindell et al. 1991, Parrish et al. 2000). Plotz et al. (2001) found that Weddell seals in the Weddell Sea in February did dive to the ocean floor, where they fed on adult Pleurogramma antarcticum which migrated to deeper depths during daytime. There was no apparent diurnal variability in the diving patterns of the seals in this study, perhaps due to the $24 \mathrm{~h}$ light regime during the time of the study.

The 3D use of space below the ice by Weddell seals from this colony suggests that the seals are searching for prey throughout their dives. On each dive they swim downwards towards the sloping ocean floor, gradually getting closer to it. This pattern suggests that they are searching within the water column rather targeting a specific depth. Further, the consistent horizontal displacement during the dives may accord with the notion that local prey are depleted near the colony and the tide crack.

\section{Individual dive profiles}

The transmission rate of the transmitters permitted a maximum rate of fix acquisition of 7.5 fixes $\mathrm{min}^{-1}$, or once every $8 \mathrm{~s}$ for each seal. In our study, several seals were usually being monitored simultaneously, which meant that the individual location rate was generally lower than this. With subsequent filtering to remove aberrant locations due to under-ice or bottom reflections, the mean location rate for the seals was less than 1 per minute. The low rate of fixes per individual was not a problem for the overall spatial use analysis, which calculated time spent in $50 \mathrm{~m}^{3}$ cells, but it did limit the number of dives that could be included in the individual dive profile analysis.

Our minimum requirement of 10 fixes per dive meant that the dives used for the individual dive profile analyses were likely to be a biased representation of the dives made by the seals. For example, the shorter dives of less than 10 min were not included. The individual dives examined do, however, include the long dives throughout the seals' preferred area of activity. The individual dive profiles support the conclusion that the seals make long searching dives with little bottom time. The main distinguishing characteristics of these dives were the amount of meander (searching), swimming speed and proximity to the bottom.

The 58 dives examined in this study could not be assigned to discrete behavioural groups on the basis of the 19 parameters used. This is in contrast to studies 
using 2-dimensional data (i.e. depth and time) which have described discrete behavioural categories (Schreer et al. 1998, 2001). The dives in our study formed a continuum from relatively fast, directional dives with little time spent at the maximum distance to slow, meandering dives. It is always difficult to assign a function to any particular dive without independent data, such as stomach temperature implants to indicate feeding events. One interpretation, which can be tested using video recording of prey capture (e.g. Davis et al. 1999), is that the more direct dives represent successful foraging attempts, where the seals have descended along a search path, encountered and captured prey, and returned quickly to the surface. At the other extreme would be unsuccessful dives where the seal continues searching throughout.

All of our seals foraged in the same area, suggesting that prey may not uniformly distributed, and that they may be in highest densities over the steeply sloping bottom in the NW region of the study site. Fish may be concentrated by the topography, which may lead to upwelling and enhanced productivity (Dewitt 1970). Focused foraging activity provides an important, but not necessarily essential, condition for local prey depletion and intra-specific competition. The 3D diving behaviour of the seals suggests that they are primarily exploiting bentho-pelagic prey such as Pleurogramma antarcticum, which may move through the area (Plotz et al. 2001) thereby avoiding long-term prey depletion. However, the degree of intra-specific competition can only be assessed by comparing the rate at which prey are consumed with the rate at which they arrive, and these data are currently unavailable.

Acknowledgements. We thank the staff of Scott Base who provided excellent field support for the 2 years of this study, and D. Bell, G. Reynolds, T. Dorr and E. Turner for their help in the field. This study was conducted with permission from the Environmental Assessment and Review Panel of Antarctica New Zealand, Department of Conservation, New Zealand, and the Animal Ethics Committee of the University of Waikato. This study was supported by the Seaworld Research and Rescue Foundation, the Graduate School of the Environment, Macquarie University, the Department of Biological Sciences, University of Waikato and the Antarctic Scientific Advisory Committee.

\section{LITERATURE CITED}

Bartsh SS, Johnston SD, Siniff DB (1992) Territorial behavior and breeding frequency of male Weddell seals (Leptonychotes weddellii) in relation to age, size, and concentrations of serum testosterone and cortizol. Can J Zool 70: 680-692

Belbin L (1993) PATN pattern analysis program. CSIRO, Canberra

Bengtson JL, Stewart BS (1997) Diving patterns of a Ross seal (Ommatophoca rossii) near the eastern coast of the Antarctic Peninsula. Polar Biol 18:214-218

Burns JM, Castellini MA (1996) Physiological and behavioural determinants of the aerobic dive limit in Weddell seal (Leptonychotes weddellii) pups. J Comp Physiol B 166:437-483

Burns JM, Testa JW (1997) Developmental changes and diurnal and seasonal influences on the diving behaviour of Weddell seal (Leptonychotes weddellii) pups. In: Battaglia B, Valencia J, Walton DWH (eds) Antarctic communities: species, structure and survival. Cambridge University Press, Cambridge, p 328-334

Burns JM, Trumble SJ, Castellini MA, Testa JW (1998) The diet of Weddell seals in McMurdo Sound, Antarctica, as determined from scat collections and stable isotope collections. Polar Biol 19:272-282

Castellini MA, Davis RW, Kooyman GL (1992) Annual cycles of diving behaviour and ecology of the Weddell seal. Bull Scripps Inst Oceanogr Univ Calif 28:1-54

Clarke MR, MacLeod M (1982) Cephalopod remains in the stomachs of eight Weddell seals. Br Ant Surv Bull 57: $33-40$

Costa DP (1991) Reproductive and foraging energetics of pinnipeds: implications for life history patterns. In: Renouf D (ed) The behaviour of pinnipeds. Chapman \& Hall, London, p 300-344

Davis RW, Worthy GAJ, Wursig B, Lynn SK (1996) Diving behaviour and at-sea movements of an Atlantic spotted dolphin in the Gulf of Mexico. Mar Mamm Sci 12:569-581

Davis RW, Fuiman LA, Williams TM, Collier SO, Hagey WP, Kanatous SB, Kohin S, Horning M (1999) Hunting behavior of a marine mammal beneath the Antarctic fast ice. Science 283:993-996

Davis RW, Fuiman LA, Williams TM, Le Boeuf BJ (2001) Three-dimensional movements and swimming activity of a northern elephant seal. Comp Biochem Physiol A 131:759-770

DeLong RL, Stewart BS (1991) Diving patterns of northern elephant seal bulls. Mar Mamm Sci 7:369-384

Dewitt HH (1970) The character of the mid water fish fauna of the Ross Sea Antarctica. In: Holdgate MW (ed) Antarctic ecology, Vol 1. Academic Press, New York, p 305-314

Fedak MA, Lovell P, McConnell BJ (1996) MAMVIS: a marine mammal behaviour visualisation system. J Visualizat Comput Animat 7:141-147

Folkow LP, Blix AS (1999) Diving behaviour of hooded seals (Cystophora cristata) in the Greenland and Norwegian Seas. Polar Biol 22:61-74

Green K, Burton HR (1987) Seasonal and geographical variation in the food of Weddell seals, Leptonychotes weddellii, in Antarctica. Aust Wildl Res 14:475-489

Green K, Burton HR, Watts DJ (1995) Studies of the Weddell seal in the Vestfold Hills, East Antarctica. ANARE Res Notes 93:1-64

Harcourt RG, Schulman AM, Davis LS, Trillmich F (1995) Summer foraging by lactating female New Zealand fur seals (Arctocephalus forsteri) off Otago Peninsula, New Zealand. Can J Zool 73:678-690

Harcourt RG, Hindell MA, Bell DG, Waas JR (2000) Threedimensional dive profiles of free-ranging Weddell seals. Polar Biol 23:479-487

Hindell MA, Slip DJ, Burton HR (1991) Diving behaviour of adult male and female southern elephant seals. Aust J Zool 39:595-619

Hindell MA, Slip DJ, Burton HR, Bryden MM (1992) Physiological implications of continuous, prolonged and deep 
dives of the southern elephant seal (Mirounga leonina). Can J Zool 70:370-379

Hooker SK, Baird RW (1999) Deep-diving behaviour of the northern bottlenose whale, Hyperoodon ampullatus (Cetacea: Ziphiidae). Proc R Soc Lond B Biol Sci 266: 671-676

Hull CL, Hindell MA, Michael K (1997) Foraging zones of royal penguins during the breeding season, and their association with oceanographic features. Mar Ecol Prog Ser 153:217-228

Knox GA (1994) The Biology of the Southern Ocean. Cambridge University Press, Cambridge

Kooyman GL, Wahrenbrock EA, Castellini MA, Davis RW, Sinnet EE (1980) Aerobic and anaerobic metabolism during voluntary diving in Weddell seals: evidence of preferred pathways from blood chemistry and behaviour. J Comp Physiol 138:335-346

Le Boeuf BJ, Crocker DE, Costa DP, Blackwell SB, Webb PM, Houser DS (2000) Foraging ecology of northern elephant seals. Ecol Monogr 70:353-382

Lydersen C, Hammill MO (1993) Diving in ringed seal Phoca hispida pups during the nursing period. Can J Zool 71: 991-996

McConnell BJ, Fedak MA (1996) Movements of southern elephant seals. Can J Zool 74:1485-1496

McConnell BJ, Chambers C, Fedak MA (1992a) Foraging ecology of southern elephant seals in relation to the bathymetry and productivity of the Southern Ocean. Antarct Sci 4:393-398

McConnell BJ, Chambers C, Nicholas KS, Fedak MA (1992b) Satellite tracking of grey seals (Halichoerus grypus). J Zool (Lond) 226:271-282

McConnell BJ, Fedak MA, Lovell P, Hammond PS (1999) Movements and foraging areas of grey seals in the North Sea. J Appl Ecol 36:573-590

McConnell BJ, Fedak MA, Burton HR, Engelhard GH, Reijnders PJH (2002) Movements and foraging areas of naïve, recently weaned southern elephant seal pups. J Anim Ecol 71:65-78

Parrish FA, Craig MP, Ragen TJ, Marshall GJ, Buhleier BM (2000) Identifying diurnal foraging habitat of endangered Hawaiian monk seals using a seal-mounted video camera. Mar Mamm Sci 16:392-412

Plotz J (1986) Summer diet of Weddell seals (Leptonychotes weddellii) in the eastern and southern Weddell Sea, Antarctica. Polar Biol 6:97-102

Plotz J, Ekau W, Reijnders PJH (1991) Diet of Weddell seals Leptonychotes weddellii at Veatkapp, eastern Weddell Sea (Antarctica), in relation to local food supply. Mar Mamm Sci 7:136-144

Plotz J, Bornemann H, Knust R, Schroder A, Bester M (2001)

Editorial responsibility: Otto Kinne (Editor),

Oldendorf/Luhe, Germany
Foraging behaviour of Weddell seals, and its ecological implications. Polar Biol 24:901-909

Ponganis PJ, Kooyman GL, Castellini MA (1993) Determinants of the aerobic dive limit of Weddell seals: analysis of diving metabolic rates, postdive end tidal $\mathrm{PO}_{2}{ }^{\prime} \mathrm{s}$, and blood and muscle oxygen stores. Phys Zool 66:732-749

SAS (1988) SAS/STAT Users Guide, Release 6.03 Edition. SAS, Cary, NC

Schreer JF, O'Hara Hines RJ, Kovac KM (1998) Classification of dive profiles: a comparison of statistical clustering techniques and unsupervised artificial neural networks. J Agric Biol Environ Stat 3:383-404

Schreer JF, Kovacs KM, Hines RJO (2001) Comparative diving patterns of pinnipeds and seabirds. Ecol Monogr 71:137-162

Simpkins MA, Kelly BP, Wartzok D (2001a) Three-dimensional movements within individual dives by ringed seals (Phoca hispida). Can J Zool 79:1455-1464

Simpkins MA, Kelly BP, Wartzok D (2001b) Three-dimensional analysis of search behaviour by ringed seals. Anim Behav 62:67-72

Sjoberg M, Ball JP (2000) Grey seal, Halichoerus grypus, habitat selection around haulout sites in the Baltic Sea: bathymetry or central-place foraging? Can J Zool 78:1661-1667

Stewart BS, Leatherwood S, Yochem PK, Heide-Jorgensen MP (1989) Harbor seal tracking and telemetry by satellite. Mar Mamm Sci 5:361-375

Tedman RA, Bryden MM (1981) Milk intake of Weddell seal young estimated by tritiated water and ${ }^{22}$ sodium turnover. Antarct J US 16:152-153

Tedman R, Green B (1987) Water and sodium fluxes and lactational energetics in suckling pups of Weddell seals (Leptonychotes weddellii). J Zool (Lond) 212:29-42

Thompson PM, Pierce GJ, Hislop JRG, Miller D, Diack JSW (1991) Winter foraging by Common seals (Phoca vitulina) in relation to food availability in the inner Moray Firth, N.E. Scotland. J Anim Ecol 60:283-294

Tollit DJ, Black AD, Thompson PM, Mackay A and 5 others (1998) Variations in harbour seal Phoca vitulina diet and dive-depths in relation to foraging habitat. J Zool (Lond) 244:209-222

Wartzok D, Elsner R, Stone H, Kelly BP, Davis RW (1992a) Under-ice movements and the sensory basis of hole finding by ringed and Weddell seals. Can J Zool 70:1712-1722

Wartzok D, Sayegh S, Stone H, Barchak J, Barnes W (1992b) Acoustic tracking system for monitoring under-ice movements of polar seals. J Acoust Soc Am 92:682-687

Zamon JE, Greene CH, Eli MT, Demer DA, Hewitt RP, Sexton S (1996) Acoustic characterization of the three-dimensional prey field of foraging chinstrap penguins. Mar Ecol Prog Ser 131:1-10

Submitted: February 26, 2002; Accepted: July 4, 2002 Proofs received from author(s): August 30, 2002 